\title{
ASSAY OF BACILLUS CEREUS EMETIC TOXIN PRODUCED IN ORANGE SQUASH
}

\author{
Sunita Singh \\ Division of Food Science and Post-harvest Technology \\ Indian Agricultural Research Institute \\ Pusa, New Delhi, 110012, India \\ sunitaiari@gmail.com \\ Prachi Lad \\ Department of Promotional \& Medical Review Solutions (for AstraZeneca, USA.) \\ Indegene Pvt. Ltd. \\ Outer Ring Road, Nagawara, Bengaluru - 560 045, Karnataka, India.
}

\begin{abstract}
The contamination of squash by $B$. cereus, an enterotoxin producer, was found to range between $7.5 \times 10^{4}$ and $1.8 \times 10^{4} \mathrm{CFU} / \mathrm{g}$ in orange squash (during storage), that is hazardous. Orange squash is widely produced and consumed in India, but has a low rating of 3 on the scale of 10 (on feedback), mostly due to high sugars, not preferred these days. It can be preserved for $>9$ months due to added sugars and preservatives. During processing squash, if juice is not quickly cooled and/or squash is kept for long at temperatures $<48^{\circ} \mathrm{C}$ after processing, it can be a source of food poisoning. Reason, a large number of toxins can be produced by $B$. cereus. B. cereus strains, isolated from squash, produce heat stable toxin. Vacuolar assay confirmed them as emetic toxins, produced in squash. The toxin behaved like an ionophore in assay using mitochondria, extracted from liver cells of chicken with potassium ions in buffer. The toxicity of toxin by assay was $3200 \mathrm{IU} / \mathrm{ng}$ (BC IV strain) and $800 \mathrm{IU} / \mathrm{ng}$ (BC X strain). By the vacuolar expansions of mitochondria in assay, toxins of B. cereus demonstrated a toxic effect, in the range of 20.93 to $60.94 \%$ by BC IV toxin and 43.28 to $45.02 \%$ by $\mathrm{BC} X$ toxin, on the $3^{\text {rd }}$ day growth of $B$. cereus in squash and toxin extraction for assay. It was also possible to produce antibodies against the B. cereus whole cell and toxin of BC IV, as an attempt to detect B. cereus contaminations in foods, by Ouchterlony's immune-diffusion test.
\end{abstract}

Keywords: Bacillus cereus, emetic toxin, chicken liver mitochondria, orange squash, vacuolar assay, antibodies.

DOI: $10.21303 / 2504-5695.2021 .001753$

\section{Introduction}

Globally the total burden due to food borne diseases is not known [1]. Bacillus cereus is a ubiquitous contaminant of foods that cannot be completely eliminated and is also known to survive at temperatures as low as $4{ }^{\circ} \mathrm{C}$ to $6{ }^{\circ} \mathrm{C}$ [2]. It is an etiological agent of two distinct forms of food poisonings, caused by its toxins, showing syndromes of the emetic and diarrheal toxins [3] with $>90 \%$ of the poisonings by $B$. cereus being due to its emetic toxin [4], produced by growth of $B$. cereus in foods [5]. The rod shaped, aerobic gram-positive bacterium produces endospores in adverse conditions. The toxin, produced by emetic strains of $B$. cereus, has immune-modulating property in the human body [6]. This toxin is a low molecular weight- heat and acid-stable depsipeptide and can withstand intestinal proteolytic enzymes [7]. The organism is widely reported in foods like rice [8,9] pasta, noodles [10], milk and milk products [11, 12], poultry products [13], cook chill meals [2], ready-to-serve meals [14], and various fruit products [15]. The toxin can maintain its activity after exposure to $126^{\circ} \mathrm{C}$ for $90 \mathrm{~min}$, and considered as one of the most stable enterotoxins [16]. It is thus advantageous to assay emetic toxins of B. cereus in contaminated foods.

The infective dose of $B$. cereus in foods is $10^{5}-10^{8} / \mathrm{g}$ [17] that can lead to emetic poisoning if ingested $[18,19]$. The toxin dose of $\leq 8 \mu \mathrm{g}$ toxin $\mathrm{kg}^{-1}$ body weight, is a toxic dose in humans and none of the enzymes in the human body are known to detoxify this toxin [20]. If present in a dose as low as 0.01 to $1.28 \mu \mathrm{g}$ emetic toxin /g food, it results in severe and acute poisoning symptoms [21].

To assay this emetic toxin, a positive vacuolar expansion (of mitochondria) confirms the toxin of B. cereus, related to emetic-syndrome (9) and is a good screening assay for toxin in foods. The vacuole activity is $\mathrm{pH}$ stable (2 to 11$)$ and resistant to proteolytic enzymes [22]. On the other 
hand, the toxin, a cereulide protein- a cyclic dodeca-depsipeptide [21, 23, 24] is tolerant and resistant to heat $[10,25]$ and highly stable with a low molecular size $\sim 1.2 \mathrm{kDa}$ [17]. Considering the ionophoretic property of emetic toxin [26], PIPES buffer containing $\mathrm{K}+$, was used in this study. The vacuolar assays confirmed toxic effects of emetic toxins, by two strains BC IV and BC X of $B$. cereus, isolated from squash. The effectiveness of the toxins ranged between $2 \%$ to $44 \%$ for $\mathrm{BC}$ IV and $4 \%$ to $9 \%$ for BC X toxins, in the squash medium.

The antigenic potential of emetic toxin of $B$. cereus has been reported to be very poor in rhesus monkey, compared to Staphylococcal enterotoxin [16]. However still, an attempt, made to raise antibodies against $B$. cereus strain BC IV and its emetic toxin in rabbits (New Zealand White males), yielded positive results, presented herein.

\section{Materials and Methods}

Preparation of Squash: Orange squash, assessed for specific organism Bacillus cereus counts, was prepared (Fig. 1) with fruit juice using the standard protocol [27].

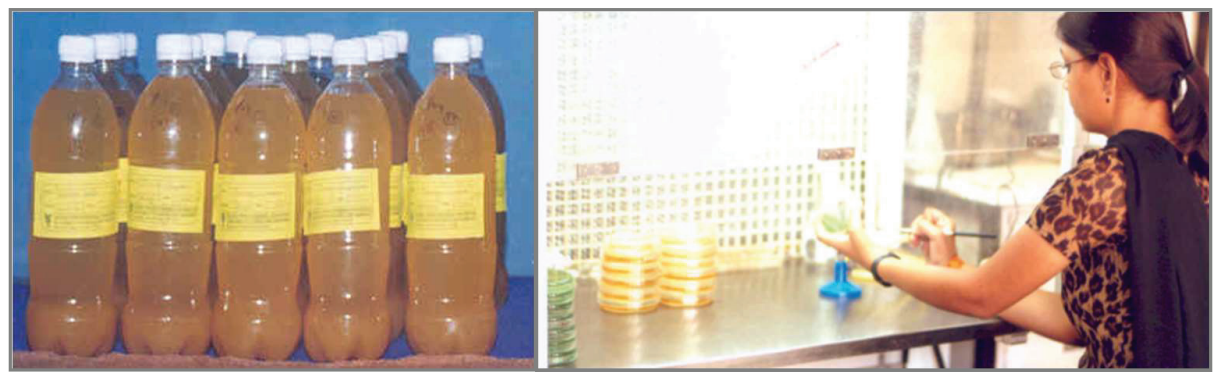

Fig. 1. Packed Orange Squash. Isolation and Enumeration of cultures (experimental works)

\section{1. Media and Solutions}

Polymyxin Egg-yolk Thymol Blue Agar (PEMBA) (with Mannitol) (pH 7.2 \pm 0.2 ) [28]; Butterfield's phosphate buffered dilution water; Nutrient Broth and Nutrient Agar Medium (Hi-media); Plate count Agar (Hi-media) [29]. Solutions for Vacuolar assay: 0.25 M Sucrose solution $250 \mathrm{~mL}$; $100 \mathrm{~mL}$ of Buffer [100 mM KNO $+10 \mathrm{mM}$ Piperazine N-N'-bis [2 ethanol sulphonic acid (PIPES)] pH 7.2.

\section{2. Enumeration of $\boldsymbol{B}$. cereus counts}

Spread Plate method was used to enumerate the microbial load (for required fruit products), on PEMB agar medium. If the quantity of food to be examined was large, uniformly distributed representative samples of the fruit product $(50 \mathrm{~g})$ were used. The samples of $10^{2}$ to $10^{6}$ dilutions were plated for enumeration. The enumeration of B. cereus in squash on PEMBA: Aliquots from the experimental flasks were diluted into $0.1 \%$ Butterfield's phosphate buffered dilution water $\left(10^{2}-10^{7}\right.$ dilutions), surface was plated $(0.2 \mathrm{~mL})$ on PEMBA medium in $90 \mathrm{~mm}$ dia petri plates and spread evenly, and incubated $\left(30^{\circ} \mathrm{C}\right)$ for 5 days growth and counted $(\mathrm{CFU} / \mathrm{mL})$ at 1,3 and 5 days after inoculation. Arithmetic counts were converted to $\log _{10} \mathrm{CFU} / \mathrm{mL}$ values.

\section{3. Isolation and cultural characteristics of the strains}

Standard procedures $[29,30]$ were followed to isolate $B$. cereus from squash. Preserved (60 days) squash sample(s) were serially diluted $\left(10^{-2}\right.$ to $\left.10^{-5}\right)$ in autoclaved Butterfield's phosphate buffered dilution water. The dilutions were plated in replicates $(0.2 \mathrm{~mL})$, on PEMBA and incubated $24 \mathrm{~h}$ at $30^{\circ} \mathrm{C} \pm 2{ }^{\circ} \mathrm{C}$. Colonies, presenting a peacock blue colour with precipitation zone/halo, due to egg yolk hydrolysis (lecithinase test) were considered positive and were enumerated [31]. The lecithinase positive and mannitol utilization negative colonies of $B$. cereus [32], were picked from plates, purified and transferred to nutrient agar slants. Care was taken not to pick colonies turning yellow (mannitol utilizing colonies) [28]. 


\section{4. Biochemical characteristics of the B. cereus strains}

Standard procedures were followed for Voges-Proskauer Reaction ( $\mathrm{pH} 7.5$ ) in GP- (Glucose phosphate) broth [33, 34], Gram staining, hemolysin production and lecithinase tests [31, 34]. A known reference strain $B$. cereus NCIM 2185 served as the positive control for characterization of B. cereus.

The Emetic toxin Production, Extraction, Effective toxin assay, its Toxicity test and exploring it as an immuno diagnostic tool using the isolate strains BC IV and BC X, in the order of experimentation are mentioned (Fig. 2).

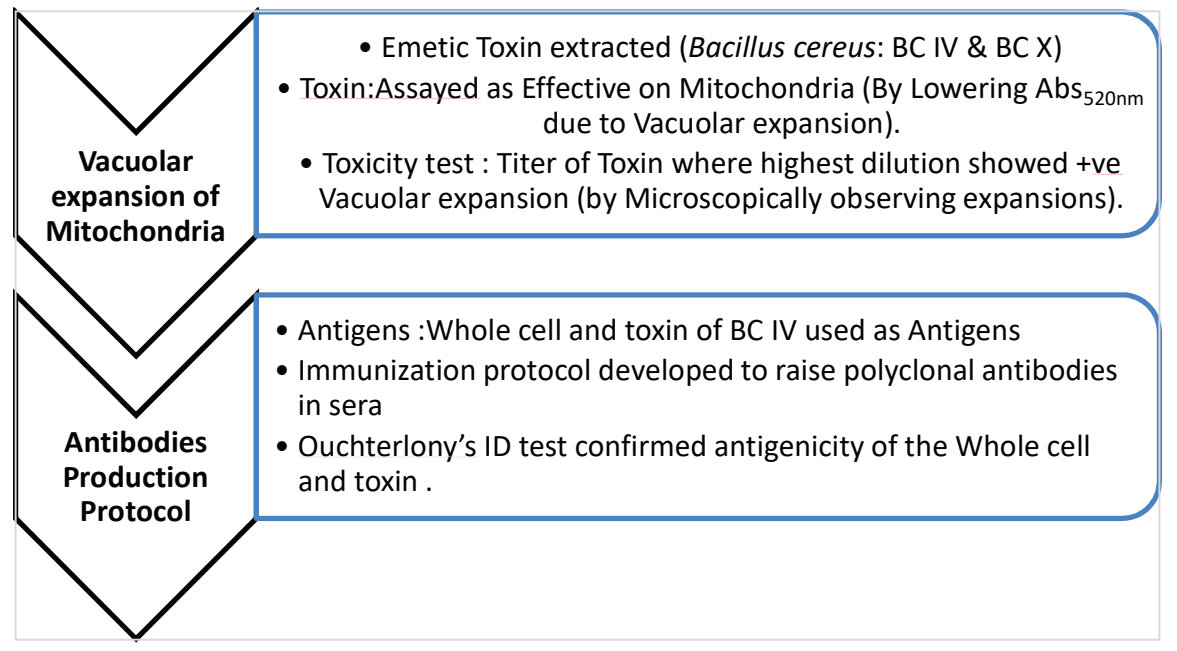

Fig. 2. Schematic showing of the steps of the Bacillus cereus Emetic toxin production and its detection

\section{5. Extraction of Mitochondria}

A fresh, liver (from a broiler chicken $\sim 1 \mathrm{~kg}$ weight, cut a BC IV and BC X fresh) was used for Extraction of Mitochondria [within an hour of procuring it] and a standard protocol [35] was followed for extraction (Fig. 3).

\footnotetext{
Chicken Liver tissue was washed in ice-cold sucrose $(0.25 \mathrm{M} \mathrm{pH} 7.2) \quad$ Cut into small pieces Homogenized in sucrose $(0.25 \mathrm{M})(1 \mathrm{~g} / 10 \mathrm{~mL})$ Tissue was macerated gently in a pestle and mortar with $0.02 \%$ EDTA and $0.25 \%$ Trypsin solution. The resultant suspension was allowed to stabilize for 10 minutes in ice bath and centrifuged at $500 \mathrm{~g}$ for 1 minute and then again for 5 minutes Supernatant (Reject Sediments of Cell debris \& Nuclei) Centrifuged at $8000 \mathrm{~g}$ for 10 minutes Pellet (Sediment mitochondria $\left(\mathrm{CLM}^{\#}\right)$ fraction) $(0.05 \mathrm{~g} / \mathrm{mL})$ in $0.25 \mathrm{M}$ sucrose (Supernatant rejected) [ \# Chicken liver mitochondria].
}

Fig. 3. Extraction of mitochondria from chicken liver cells

\section{6. Buffered Mitochondrial suspension-}

Chicken liver mitochondria (CLM) were suspended in $0.25 \mathrm{M}$ sucrose solution $(0.05 \mathrm{~g} / \mathrm{mL})$ $(0.01,0.02,03,04,05,0.1,0.2 \mathrm{~mL})$ in $4.0 \mathrm{~mL}$ buffered $\mathrm{KNO}_{3}\left(100 \mathrm{mM} \mathrm{KNO}_{3}+10 \mathrm{mM}\right.$ Piperazine N-N'-bis [2 ethanol sulphonic acid (PIPES), $\mathrm{pH}$ 7.2. The final volume was made up to $4.4 \mathrm{~mL}$.

Production of Emetic Toxin:

a) in Orange squash: A 48 h culture growth of Bacillus cereus BC IV, was scrapped from two slants with $20 \mathrm{~mL}$ distilled water. The suspension was diluted to adjust $\mathrm{OD}_{600}$ of 1.0. The inoculum of $100 \mu \mathrm{L}$ was added into sterilized squash $(150 \mathrm{~mL})$. The culture growth 
in squash was centrifuged (on day $1,3 \& 5$ ) $\sim 2000 \times \mathrm{g}$ for 20 minutes to extract toxin (supernatant). The toxin was heated at $100{ }^{\circ} \mathrm{C}(7 \mathrm{~min})$ to denature heat-labile diarrheal toxin of $B$. cereus before use for assay;

b) in Nutrient broth [Titer determination \& Toxicity test of toxin] Cultures (BC IV\&X), grown in agar slants were diluted in NB. A suspension $\left(150 \mu L\right.$ having $\left.\sim 1 \times 10^{3} \mathrm{CFU} / \mathrm{mL}, \mathrm{OD} \sim 1.0\right)$ of $B$. cereus culture inoculum was added to make a total volume of $150 \mathrm{~mL}$ nutrient broth (in $500 \mathrm{~mL}$ Erlenmeyer flasks), incubated at $30^{\circ} \mathrm{C} \pm 2{ }^{\circ} \mathrm{C}(100 \mathrm{rpm}$ in shaker) for $48 \mathrm{~h}$. Cultures were diluted in NB to give final concentrations of approximately $1 \times 10^{3} \mathrm{CFU} / \mathrm{mL}$ in triplicate [36, 37]. The growth in medium was centrifuged at $\sim 2000 \times \mathrm{g}$ for 30 minutes $\left(4^{\circ} \mathrm{C}\right)$. The molecular size of toxin (cereulide) is $<1.2 \mathrm{kda}$. The cell pellet was separated and the supernatant (toxin extract) collected, filtered through $0.4 \mu \mathrm{m}$ membrane filter, to produce toxin extract of B. cereus [23]. The toxin supernatant was heat-treated $\left(100^{\circ} \mathrm{C}\right.$ for $5-7$ minutes) to denature heat-labile diarrheal toxin of $B$. cereus, prior to assay for use as emetic toxin;

c) the maximum population density of $B$. cereus (MPD): The Maximum population density (MPD) in a 5 days growth of $B$. cereus strains (BCIV \& BCX), during toxin production in squash, was recorded and expressed as $\log _{10} \mathrm{CFU} / \mathrm{mL}$;

d) biochemical changes in squash, used for toxin production: After inoculation of B. cereus strains, to produce toxin in squash, Reducing sugars and total Titratable acidity were assessed [27].

Vacuolar assay for effect of emetic toxin. The toxin was assayed on mitochondria expansions (Fig. 2). The toxin, produced either in squash or in Nutrient broth, was used for spectrophotometric and microscopic observations, respectively. Since emetic toxin has the potassium ionophore property, it may then selectively help in the uptake of $\mathrm{K}+$ by mitochondria in such a way so as to be a cause of swelling, or vacuoles $[24,38,39]$. Other changes with inter-membrane spaces of mitochondria are a result of toxicity [40], leading to expansions, recognized as emetic activity of toxin. The $\mathrm{K}+$ containing PIPES buffer was thus used to suspend CLM.

Spectrophotometric assay \& quantification of Mitochondrial Expansion by Emetic toxin $[26,36]$. The main criterion to assay $B$. cereus emetic toxin $[5,41,42]$, was to assess if it was effective in a buffer suspension chosen, in this study.

Mitochondria were extracted and suspended in sucrose solution along with heat treated toxin (in presence of $\mathrm{K}^{+}$cations in nitrate containing PIPES buffer solution $\mathrm{pH}$ 7.2) (Fig. 3). The vacuolar swellings in mitochondria in presence of toxin [26] were observed spectroscopically and reported as the effectiveness of toxin. The absorbance was observed with UV-VIS spectrophotometer (Model DIGSPEC $200 \mathrm{GL}$ ) using glass cuvettes. The swelling of mitochondria was observed as lowering of absorbance $\left(\lambda_{520 \mathrm{~nm}}\right)$ due to toxin, and compared to control (without toxin). The various combination- mixes, of mitochondrial fractions $(0.05,0.04,0.03,0.02,0.01 \& 0.1 \mathrm{~mL})$ in $\mathrm{KNO}_{3}$ buffer solution with emetic toxin $(\mathrm{BC}$ IV/BC X) supernatants $(0.1 \mathrm{~mL}$ or $0.2 \mathrm{~mL})$, and in a total volume of $4.0 \mathrm{~mL}$ were made up to $4.4 \mathrm{~mL}$ with distilled water. These expansions were assayed due to $B$. cereus strains $\mathrm{BC}$ IV and $\mathrm{BC} X$ on $1^{\text {st }}, 3^{\text {rd }} \& 5^{\text {th }}$ days of growth of organism using a mix of CLM with toxin volumes $(0.1 \mathrm{~mL}$ or $0.2 \mathrm{~mL})$, observed between 0 to 20 minutes exposure. The exposure to the toxin remained constant for experimental period of at least 4 hours $(9,21)$, in which the observations were conducted (at $30{ }^{\circ} \mathrm{C}$ ). The $\mathrm{Abs}_{520 \mathrm{~nm}}$ values were recorded in a 20 min period (with 5 min intervals, against blank without toxin). These trials, ascertained the toxic effects on mitochondria. All assays were run in duplicates.

Based on the results, it was observed, that the toxin was effective hence its titer (toxicity) also was determined as follows.

Toxicity test of Emetic toxin extracts for titer determination [9, 21, 36]. The toxin supernatants, filter sterilized and heated at $100{ }^{\circ} \mathrm{C}$ for $10 \mathrm{~min}$, were used in the assay:

a) toxin extracts, $25 \mu \mathrm{L}$ aliquots of BC IV\&BC X, were diluted (two-fold) in buffered potassium nitrate $\left(\mathrm{KNO}_{3}\right)$ solution $\left(100 \mathrm{mM} \mathrm{KNO}_{3}+10 \mathrm{mM}\right.$ PIPES) ( $\left.\mathrm{pH} 7.0\right)$ across 12 wells of a 96-well micro-titer plate \{until 1: 4096 dilution level : (1/2, 1/4, 1/8, 1/16, 1/32, 1/ 64, 1/128, 1/256, 1/512, $1 / 1024,1 / 2048,1 / 4096)\}$, in duplicate;

b) a $100 \mu \mathrm{L}$ suspension of mitochondria (trypsinized) fraction from Chicken liver cells, [0.05 g cells $/ \mathrm{mL}$ in $0.25 \mathrm{M}$ sucrose medium (Fig. 2)], was added into each of the dilution volumes 
$(25 \mu \mathrm{L})$ of emetic toxin. After 10 minutes reaction, smears were prepared on clean glass slide from each dilution, air-dried, stained with indigo carmine solution $(0.1 \%)$ and then dried in air;

c) the morphological effect of toxin (mitochondrial expansion) was observed under binocular microscope (Leitz) (at $40 \mathrm{X}$ and $100 \mathrm{X}$ (Oil immersion lens) and also compared with the control (without toxin) slide;

d) the highest dilution that showed the Positive morphological effect (vacuolar expansion) was observed as a positive toxin effect on mitochondria. The inverse of the highest dilution of toxin that showed vacuoles was recorded as the titer of toxin. An average of 3 observed fields of the dilution, with a minimum 10 vacuoles/field was recorded. A positive vacuolar expansion in the assay, confirmed the emetic toxin activity [21] of the strains BC IV \& BC X. The minimum dose of titer of $1 \mathrm{U}$ was measured as $5 \mathrm{ng} / \mathrm{mL}[24,43]$. Based on $1 \mathrm{U}$ value, the titer of $B$. cereus toxins of BC IV and BC X were calculated.

Production of polyclonal antibodies of the whole cell and emetic toxin of B. cereus strain BC IV.

The possibility to raise polyclonal antibodies (against the BC IV-whole cell antigen (WC$\mathrm{Ag}$ ) and emetic toxin Ag (Tx-Ag), a possible tool to detect B. cereus or its toxin in foods, was explored. The antigens (Ag) of B. cereus strain BC IV\&BC X were prepared (Table 1).

Table 1

Preparation of Antigens - Whole cell (Ag) and Emetic toxn (Ag) for use in Immunizations [15]

\begin{tabular}{|c|c|}
\hline Object & Description \\
\hline $\begin{array}{l}\text { Production of polyclonal antibodies } \\
\text { of the whole cell and emetic toxin of } \\
\qquad \text { B. cereus strain BC IV }\end{array}$ & $\begin{array}{l}\text { B. cereus culture isolate BC IV, was grown in } 250 \mathrm{~mL} \text { Nutrient broth medium in four } \\
500 \mathrm{~mL} \text { Erlenmeyer flasks under shaking }(100 \mathrm{rpm}) \text { at } 30^{\circ} \mathrm{C} \pm 2{ }^{\circ} \mathrm{C} \text { for } 4 \text { days to obtain } \\
\text { cellular growth and toxin supernatant, for use as antigens. }\end{array}$ \\
\hline Whole cell BC IV (Ag) & $\begin{array}{l}\text { Cellular fraction was centrifuged and suspended in phosphate buffer saline ( } \mathrm{pH} 7.0)[\mathrm{PBS}] \text { and } \\
\text { stored }\left(-20^{\circ} \mathrm{C} \text { ) in small volumes in vials. The suspension was diluted to adjust to } 10^{6} \mathrm{CFU} / \mathrm{mL}\right. \\
\left.\text { (at } \mathrm{Abs}_{600 \mathrm{~nm}} \text { to } \sim 1.0 \text { ), with phosphate buffer saline ( } \mathrm{pH} 7.0\right) \text {, before for use in immunization. }\end{array}$ \\
\hline Toxin fraction BC IV (Ag) & $\begin{array}{l}\text { The toxin fraction was also stored }\left(-20^{\circ} \mathrm{C}\right) \text { in small volumes in vials. It was diluted to half } \\
\text { its concentration with }[\mathrm{PBS}] \text { before for use in immunization. }\end{array}$ \\
\hline $\begin{array}{l}\text { New Zealand White male rabbits as } \\
\text { animal for experimentations }\end{array}$ & $\begin{array}{l}\text { The schedule (Table 2) of intravenous and intramuscular immunization schedule was fol- } \\
\text { lowed (Fig. 4) for raising antisera against: BC IV whole cell (WC-Ag)\&BC IV toxin (Tx-Ag). }\end{array}$ \\
\hline & $\begin{array}{l}\text { New Zealand White male rabbits: } \\
\text { 1) } 2 \mathrm{~kg} \text { by weight was used for WC-Ag; }\end{array}$ \\
\hline
\end{tabular}

Antibodies Production Protocol in Rabbits.

After procuring the rabbits, they were initially fed and let to get use to the new environment for 10 days as well as to have a check on their proper health before immunizations. Antisera for B. cereus strain BC IV cellular and toxin fractions were raised in two separate rabbits as per schedule (Table 2). On day 1, pre-immunization blood was collected, (15 mL) for control rabbit serum. The schedule of intravenous (Iv) and intramuscular $\left(I_{M}\right)$ immunizations was followed until booster doses. The immunization booster dose $\left(I_{M}\right)$ for whole cell $(A b)$ at 90 days and for toxin $(\mathrm{Ab})$ at 83 days was completed. On 7 days after completion, a high volume of blood was collected for sera $(A b s)$.

For final bleeding, the rabbit was restrained and outer surface ear was cleaned with alcohol. The blood sample was taken from the auricular artery of the ear. After blood collection, direct pressure was applied to the ear with sterile cotton to prevent bruising and unnecessary bleeding. The ears were cleaned with alcohol and rabbit was allowed to relax.

An extra booster dose, after 15 days of blood collection, did not help to increase the titer of serum.

The rabbits were observed daily, and any lesions if present were taken care of. Blood collections were stored in smaller volumes $\left(-20{ }^{\circ} \mathrm{C}\right)$. 
The Ouchterlony's double diffusion test was used to study the banding patterns due to toxin sera interaction with different cellular antigens of different Bacillus cereus strains.

Table 2

Immunization Schedule (15) followed for Antibodies Production

\begin{tabular}{|c|c|c|c|}
\hline Day & Injection & $\begin{array}{c}\text { Amounts/Volumes*** per Rabbit }(* * \text { Serum vol- } \\
\text { umes are approximate) }\end{array}$ & Blood Collection \\
\hline 0 & $\begin{array}{l}\text { Primary In- } \\
\text { jection } I_{V}^{\#}\end{array}$ & $\begin{array}{l}2.0 \mathrm{ml} \text { of } \mathrm{Ag}^{*} \text { (diluted with PBS1:1)+Conjugate } \\
\text { solution: Freund's Complete adjuvant }\end{array}$ & Pre-bleed (blank sera) before injection \\
\hline 30 & First $I_{M}^{\$}$ & $\begin{array}{c}\mathrm{Ag}^{*} \text { solution (1:1) containing } 500 \mu \mathrm{g} \text { protein: Fre- } \\
\text { und's Incomplete adjuvant }\end{array}$ & - \\
\hline 45 & $I_{M}$ & Ag* solution $(1: 1)$ & - \\
\hline 60 & $I_{M}$ & Ag* solution $(1: 1)$ & - \\
\hline 75 & $I_{M}$ & Ag* solution $(1: 1)$ & - \\
\hline 83 & $I_{M}$ & $\mathrm{Ag}^{*}$ solution $(1: 1)$ & Toxin (Last dose) \\
\hline 90 & $I_{M}$ & Ag* solution $(1: 1)$ & Cellular (Last dose) \\
\hline 110 & $I_{M}$ & Ag* solution $(1: 1)$ & $\begin{array}{l}\text { Final bleed of Toxin and Cellular Ag injected } \\
\text { rabbits respectively }\end{array}$ \\
\hline
\end{tabular}

Note: $I_{V}^{\#}$-Intravenous injection; $I_{M}^{\$}$-Intramuscular injection on thigh.

\section{Results and Discussion}

Orange squash (Kissan) is one of the summer drinks in India. The high content of sugar and preservatives gives it a rating of 3 on a scale of 10 [44]. In spite of high sugar content, the drink can be hazardous, when a pathogen like Bacillus cereus, can inhabit/adapt to the medium, which can emerge as a specific ecotype [45] to B. cereus. Along the food chain, it is also very unclear as to how pathogens originate or are transmitted, that many pathogenic organisms show their presence in newer/processed- foods. In scanning microbial loads of processed products, Bacillus cereus was present in orange squash, sweet mango and papaya bars and tomato pulp (Table 3).

Table 3

Bacillus cereus load (CFU/g) in different heat-treated fruit products

\begin{tabular}{|c|c|c|c|c|c|}
\hline \multirow{2}{*}{ Bacillus cereus counts (CFU/g) } & \multicolumn{5}{|c|}{ Storage period (days) } \\
\hline & 0 & 30 & 45 & 60 & 90 \\
\hline Mango bar* $\left(\times 10^{1} \mathrm{CFU} / \mathrm{g}\right)$ & $13.80 \pm 0.36$ & $18.62 \pm 0.45$ & $33.51 \pm 2.36$ & $64.32 \pm 2.54$ & $59.20 \pm 3.21$ \\
\hline Papaya bar*×101 CFU/g & $45.02 \pm 1.25$ & $49.61 \pm 2.14$ & $68.64 \pm 4.53$ & $92.64 \pm 4.89$ & $164.03 \pm 1.87$ \\
\hline Tomato pulp* $\left(\times 10^{1} \mathrm{CFU} / \mathrm{g}\right)$ & $2.31 \pm 0.21$ & $1.65 \pm 0.30$ & $5.63 \pm 0.27$ & $4.36 \pm 0.54$ & $2.66 \pm 0.68$ \\
\hline Orange squash $\left(\times 10^{3} \mathrm{CFU} / \mathrm{g}\right)$ & $75.2 \pm 5.23$ & $62.0 \pm 0.25$ & $17.90 \pm 0.32$ & - & - \\
\hline
\end{tabular}

Note: *Source: [15].

Other foods like Soymilk (overnight refrigerated), soy tofu, blanched soybeans, tomato pulp powder from blanched tomatoes (preserved $>9$ months), maize and soy blended extruded products also contain B. cereus [15] in appreciable numbers. A high population of $B$. cereus in orange squash resulted in a decision to examine it as a medium to produce toxin by inoculation of this organism and assay presence of emetic toxin, produced by two isolates of $B$. cereus.

\section{1. Morphological and Biochemical Characteristics of Bacillus cereus strains}

The bacterial colonies (BC IV and BC X, from pineapple and orange squash respectively) were enumerated and the typical peacock bluish colonies were isolated on PEMBA medium (Fig. 4, 5). They were characterized (Fig. 4, 5, Table 4) and confirmed as Bacillus cereus strains [28-30, 34]. 
Table 4

Characteristics of Bacillus cereus strains

\begin{tabular}{|c|c|c|c|c|c|c|c|}
\hline S. No & $\begin{array}{c}\text { B. cereus } \\
\text { strain }\end{array}$ & $\begin{array}{c}\text { Colour (size- } \\
\text { Dia., mm) of colony } \\
\text { on NA medium } \\
\end{array}$ & $\begin{array}{c}\text { Smoothness } \\
\text { Edges/margin of } \\
\text { colony on PEMBA }\end{array}$ & $\begin{array}{c}\text { Crystal } \\
\text { inclusion }\end{array}$ & $\begin{array}{c}\text { Blood AgarT- } \\
\text { est** Hemolytic } \\
{[24-48 \text { hrs] (+/-) }}\end{array}$ & $\begin{array}{c}\text { Voges Proskau- } \\
\text { er Test [24 hrs] } \\
(+/-) \\
\end{array}$ & $\begin{array}{c}\text { Citrate Utili- } \\
\text { zation [7 days] } \\
(+/-) \\
\end{array}$ \\
\hline 1 & BC IV & Dull creamish (4-7) & Edges not Smooth & - & + & + & - \\
\hline 2 & $\mathrm{BC} X$ & Creamish (1-5) & Edges not smooth & - & + & + & - \\
\hline 3 & $\begin{array}{c}\text { B. cereus } \\
\text { NCIM } 2185\end{array}$ & Creamish (1-7) & Smooth edges & - & + & $+1-$ & - \\
\hline
\end{tabular}

Note: **++: large clear zones; +: large zones, but not clear (Fig. 6); $\pm:$ zones are not clear

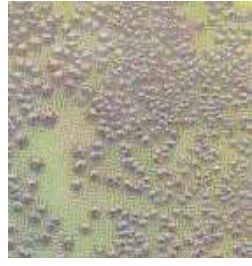

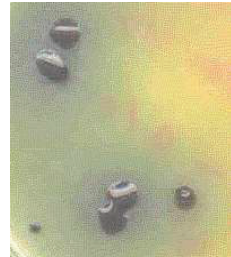

$b$

Fig 4. Bacillus cereus culture, plated for different dilutions on PEMBA medium, showing colonies, observed on plates with the sample: $a$ - at dilution $10^{-3} b-$ at dilution $10^{-6}$

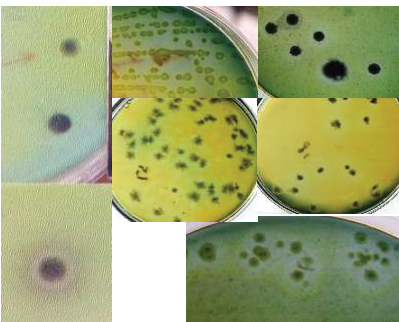

$a$

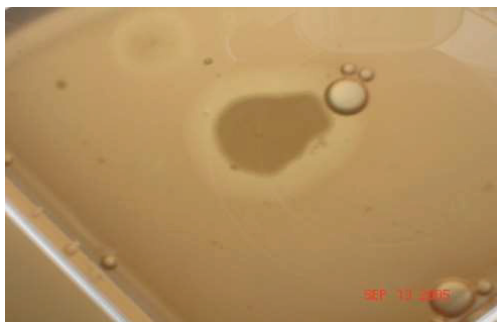

$b$

Fig 5. B. cereus strains isolates, on PEMBA medium (showing Mann-, Lecith+ colonies): $a$ - BC IV (upper row right) \& BC X (lower row right) isolated, among other isolates of $B$. cereus strains; $b$-Bacillus cereus BC IV, showing weak hemolysis on the Blood agar medium-

\section{2. Orange squash as a medium for toxin production by $\boldsymbol{B}$. cereus strains:}

The orange squash as a medium for $B$. cereus (BC IV \& BC X) inoculation showed the increase in acidity by $28-30 \%$ and total reducing sugars by $16-21 \%$, in 5 days (Table 5).

\section{Table 5}

Changes in total acidity (\%TA) and total reducing sugars (TRS), of orange squash (inoculated with BC IV \& BC X), in 5 days

\begin{tabular}{ccccc}
\hline \multirow{2}{*}{ Day } & & \% TA & \multicolumn{2}{c}{ TRS (\% mg) } \\
\cline { 2 - 5 } & BC IV & BC X & BC IV & BC X \\
\hline $0^{*}$ & 0.43 & 0.43 & 45.90 & 45.90 \\
1 & 0.44 & 0.45 & 22.22 & 25.45 \\
3 & 0.50 & 0.50 & 40.31 & 37.00 \\
5 & 0.55 & 0.56 & 53.33 & 55.54
\end{tabular}




\section{3. Production and Extraction of Bacillus cereus Emetic Toxin}

The presence of $>10^{3} \mathrm{CFU} / \mathrm{g}$ in squash can cause foodborne illness and hence it was important to understand the toxicity and effectiveness of a toxin, produced by B. cereus. In the vacuolar assay, a threshold concentration of the cereulide, can lead to the loss of mitochondrial membrane potential in human cells, which is similar to that, observed in boar sperm mitochondria during expansion, due to the cereulide (emetic toxin). Human killer cell mitochondria were reported as equivalent to boar semen [20] and that boar sperms were equally sensitive to cereulide [36]. This vacuolar assay thus establishes the toxin effect, as if it were to be present in a human body. However since boar semen was difficult to obtain, we assayed mitochondrial expansions using CLM in the assay, instead. The vacuolar assay of $B$. cereus emetic toxins showed, that the extracted heat treated toxins (BC IV and BC X) were effective (toxic) on CLM, reported as the extent of expansions, were also related with the extent of growth of the organism (Table 6). The results showed that:

1) the growth of B. cereus in squash reached the maximum population density (MPD) of $\log 10 \mathrm{CFU} / \mathrm{mL}$ of 8.00 to 10.2 , on $5^{\text {th }}$ day;

2) that B. cereus produces toxins in the end of the logarithmic growth phase of the organism and is known to be independent of sporulation [46, 47]. The toxin effectiveness from $3^{\text {rd }}$ day's growth (in late logarithmic growth stage it was high as compared to other days ( $1^{\text {st }}$ or $5^{\text {th }}$ day). The specific microbial load of $B$. cereus also reached the peak value of $\sim \log _{10}$ CFU/mL of 7.38-10;

3 ) the effectiveness of the toxin assay declined on $5^{\text {th }}$ day. By neutralizing toxin or using un-neutralized toxin, of both strains, a decrease in effectiveness of $5^{\text {th }}$ day's toxin extract as compared to $3^{\text {rd }}$ day's extract was observed. However so BC X toxin (un- neutralized) was as effective $(43-45 \%)$ as the neutralized toxin (45\%) of $3^{\text {rd }}$ day. On the other hand, the effect of un-neutralized BC IV toxin showed ( $\sim 61 \%$ lowering of the toxic effect) compared to its neutralized counterpart in assay conditions. The assay thus showed that the toxins of both strains did not have the same efficacy, even if produced in the same medium or are extracted at the same stage of growth of $B$. cereus. The production of toxin was definitely related to cell concentration of the organism in growth [21];

4) B. cereus strains could be differentiated on their toxicity levels based on extent of mitochondrial expansions due to toxin (neutralized or otherwise);

5 ) this assay may be extended to check toxicity of $B$. cereus emetic toxin directly from other foods.

The heat stable emetic toxin was effective and active (as un-neutralized toxin) at low $\mathrm{pH}$ also [16]. Thus toxin is active in stored foods, unlike the diahorreal toxin, where activity of the toxin can be eliminated or reduced under variable conditions. Thus, potential hazard of emetic toxin as shown by their toxicity when extracted cannot be ignored.

Table 6

Toxic effects (mitochondria swelling) of B. cereus toxins of BC X and BC IV from squash after inoculation with $10^{6} \mathrm{cfu} \mathrm{mL}^{-1}$ of cultures $\mathrm{BC} \mathrm{X}$ and $\mathrm{BC}$ IV in orange squash

\begin{tabular}{|c|c|c|c|c|c|c|c|}
\hline Day & $\begin{array}{l}\text { Toxin }{ }^{\#} \text { add- } \\
\text { ed }(+/-)\end{array}$ & $\begin{array}{c}\text { CFU/mL in } \\
\text { squash }\end{array}$ & $\begin{array}{l}\text { Expansion } \\
\text { time (min) }\end{array}$ & $\begin{array}{l}\text { \% Decrease in Abs } \\
\text { by BC X Toxin }\end{array}$ & $\begin{array}{c}\text { CFU/mL in } \\
\text { squash }\end{array}$ & $\begin{array}{l}\text { Expansion } \\
\text { time (min) }\end{array}$ & $\begin{array}{l}\text { \% Decrease in Abs } \\
\text { by BC IV Toxin }\end{array}$ \\
\hline \multicolumn{8}{|c|}{ Neutralized Toxin $(+)$} \\
\hline 1 & + & $1.0 \times 10^{6}(6)$ & 20 & $2.58[0.04+0.1]^{\$}$ & $24.0 \times 10^{6}(7.38)$ & 20 & $1.16[0.04+0.1]$ \\
\hline 3 & + & $1.0 \times 10^{6}(6)$ & 20 & $44.68[0.01+0.2]$ & $24.0 \times 10^{6}(7.38)$ & 5 & $60.94[0.04+0.1]$ \\
\hline 5 & + & $202.1 \times 10^{8}(8)$ & 20 & $13.76[0.01+0.2]$ & $158 \times 10^{8}(10.20)$ & 20 & $2.11[0.04+0.2]$ \\
\hline \multicolumn{8}{|c|}{ Un Neutralized Toxin -) } \\
\hline 1 & - & \multirow{2}{*}{$1.0 \times 10^{6}(6)$} & 15 & $19.35[0.05+0.1]$ & \multirow{2}{*}{$24.0 \times 10^{6}(7.38)$} & 20 & $14.45[0.04+0.1]$ \\
\hline 1 & - & & 20 & $12.07[0.1+0.2]$ & & 20 & $12.07[0.04+0.2]$ \\
\hline 3 & - & \multirow{2}{*}{$179.0 \times 10^{8}(8)$} & 15 & $43.28[0.03+0.1]$ & \multirow{2}{*}{$123 \times 10^{8}(10.09)$} & 5 & $7.04[0.04+0.1]$ \\
\hline 3 & - & & 10 & $45.02[0.05+0.2]$ & & 20 & $20.93[0.02+0.2]$ \\
\hline 5 & - & \multirow{2}{*}{$202.1 \times 10^{8}(8)$} & 20 & $5.17[0.02+0.1]$ & \multirow{2}{*}{$158 \times 10^{8}(10.20)$} & 20 & $13.60[0.04+0.1]$ \\
\hline 5 & - & & 20 & $31.48[0.01+0.2]$ & & 15 & $6.45[0.04+0.2]$ \\
\hline
\end{tabular}

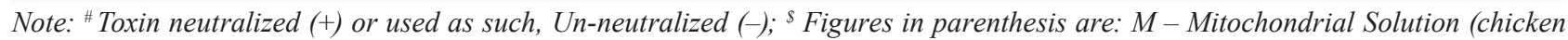
liver) $+T$ - Toxin Extract (supernatant heat treated) in reaction mix to observe vacuolar expansion of Mitochondria (in $m L$ ); Abs ${ }_{520}$ : Percentage decrease in Absorbance at $\lambda_{520 n m} ; C F U / m L$ squash figures in parenthesis are $\log _{10} C F U / m L$. 


\section{4. Toxicity Test and Microscopic Examination of Titer of $B$. cereus Toxin:}

The assay of emetic toxins (Fig. 2) showed high toxicity [21], with toxic concentration of BC IV $>$ BC X. In the vacuolar assay with respect to B. cereus toxins BC IV and BC X were observed at highest toxin dilutions of $1 / 2048$ and 1/512, respectively (Fig 6, Table 9). The concentration of toxin was calculated from the titer value in the total assay volume $(125 \mu \mathrm{L})$ (Table 7). B. cereus $\mathrm{BC}$ IV and BC X toxins were toxic at $3200 \mathrm{IU} / \mathrm{ng}$ and $800 \mathrm{IU} / \mathrm{ng}$ respectively.

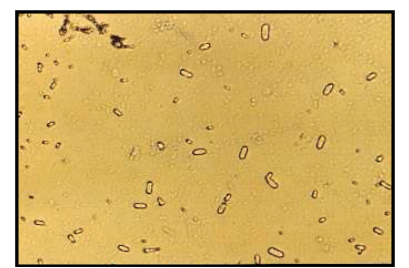

$a$

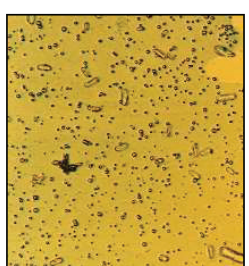

$b$

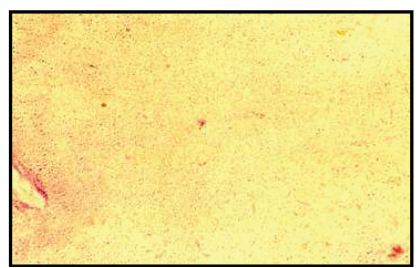

$c$

Fig. 6. Mitochondrial expansion seen $(100 \mathrm{X})$ at a different dilutions of toxins in the assay: $a-\mathrm{BC}$ IV; $b-\mathrm{BC}$ X under microscope; $c$ - Liver cells only (control) (Bottom) (Table 7)

Table 7

Test of toxicity (by Vacuolar assay^) of Emetic toxins of B. cereus strains BC IV and BC X, produced in Nutrient broth

\begin{tabular}{|c|c|c|c|c|c|}
\hline S. No. & $\begin{array}{l}\text { B. cereus strain BC } \\
\text { IV toxin extract (Vol- } \\
\text { ume } \mu \mathrm{L})\end{array}$ & $\begin{array}{c}\text { Toxin } \operatorname{Titer}^{\circledR} \text { in total assay volume } \\
\left(125 \mu \mathbf{L}^{\$}\right) \\
\text { of Emetic toxin } \\
\left(25 \mu \mathbf{L}^{\mathrm{R}}\right)+\mathbf{C} \mathbf{L} \mathbf{M}^{\#}(100 \mu \mathrm{L})\end{array}$ & $\begin{array}{c}\text { CLM solution } \\
\text { in total assay } \\
\text { volume }(\mu \mathrm{L})\end{array}$ & Titer/mL & $\begin{array}{l}\text { Toxin concentra- } \\
\text { tion* (IU/ng) }\end{array}$ \\
\hline 1 & BC IV & 2048 & 100 & 16384 & 3200 \\
\hline 2 & $\mathrm{BC} X$ & 512 & 100 & 4096 & 800 \\
\hline
\end{tabular}

Note: ^ Observed under Microscope (See, Fig 6); @ Highest dilution (of a two-fold dilution series of $25 \mu L$ toxin) [9] showing+ve vacuolar expansion; ${ }^{\$} 100 \mu \mathrm{L} C L M(0.05 \mathrm{~g} / \mathrm{mL}$ in $0.25 \mathrm{M}$ sucrose $)+25 \mu \mathrm{L}$ Toxin extract from 2 fold dilution series; ${ }^{R}$ Toxin, diluted with buffered potassium nitrate $\left(\mathrm{KNO}_{3}\right)$ solution (100 mM KNO$+10 \mathrm{mM}$ PIPES-buffer); ${ }^{*}$ CLM: Chicken liver mitochondria; * A titer of 1 U Natural cereulide, measured as $5 \mathrm{ng} / \mathrm{mL}$ [24, 43].

\section{5. Immunization Protocol and Immunodiffusion test}

The sera booster dose on $83^{\text {rd }}$ day (for toxin $\mathrm{Ag}$ ) and $90^{\text {th }}$ day (for cell $\mathrm{Ag}$ ), of immunization schedule (Tables 1, 2, Fig. 7) was followed by blood collection and sera preparation for antibodies. The precipitin test on serum raised showed titers of 2048 and 1024, for WC-Ab and toxin-Ab respectively. The Ouchterlony's Immuno-diffusion test with the serum antibodies against Whole cells (WC-Ag) and Emetic toxin (Tx-Ag), of B. cereus BC IV strain showed clear banding patterns, confirming that the same single strain serum can be used to detect other $B$. cereus strains that may be present in contaminated foods (Table 8, Fig. 8). It is thus possible to use serum (with polyclonal antibodies) as an alternate tool to detect $B$. cereus in foods

\section{Table 8}

Immuno-diffusion test, showing Banding pattern in $\mathrm{Ag}-\mathrm{Ab}$ reaction.

\begin{tabular}{ccc}
\hline \multirow{2}{*}{ Antigen used (Ag) } & \multicolumn{2}{c}{ Banding pattern of Antigen (Ag) with Antibody (Ab) } \\
\cline { 2 - 3 } & Cellular WC-Ab (serum) used in center well & Toxin Tx-Ab ( serum) used in center well \\
\hline BC IV Cellular WC-Ag & 4 bands & 5 bands \\
BC IV Toxin Tx-Ag & 4 bands & 5 bands
\end{tabular}

Toxin, used in a brown rabbit, Cellular Ag, used in a white rabbit (Fig. 8). 


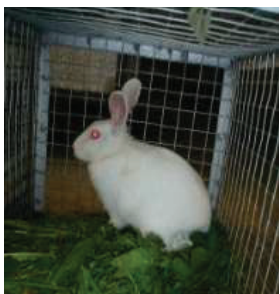

$a$

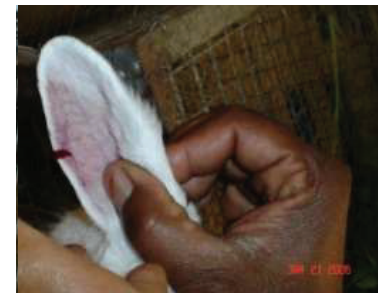

$b$

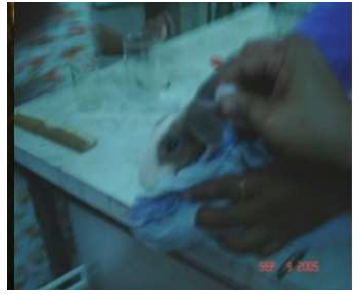

$c$

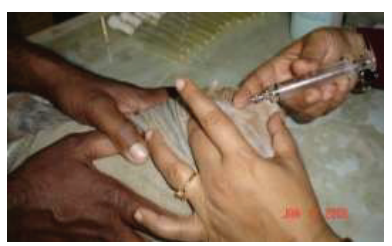

$d$

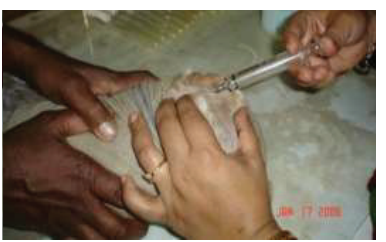

e

Fig. 7. Few steps, showing Immunization of Himalayan rabbits: $a$ - rabbit feed used;

$b$ - Pre-bleeding from lateral (auricular) artery (ear); $c$ - stoppage of flow after bleeding; $d, e-$ intramuscular immunization, as per schedule. All procedures were performed with care as per standard practices (Table 1, 2)

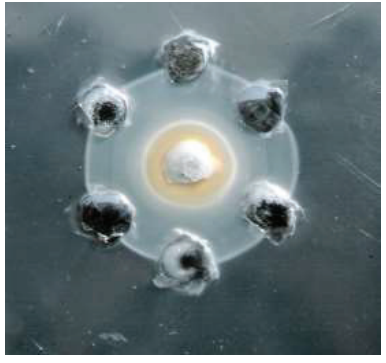

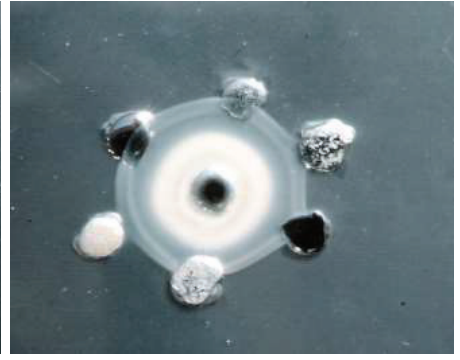

$b$

Fig. 8. Immunodiffusion test of $B$ cereus antigens: $a$ - cellular Ag in side wells banding with its antisera (in center well); $b$ - emetic toxin $\mathrm{Ag}$ in side well banding with its antisera (in center well)

\section{Conclusions}

B. cereus toxin is known to be present in foods and fruit products [48-50]. In foods their viable counts ranged between $10 \mathrm{CFU} \mathrm{mL} \mathrm{mL}^{-1} / \mathrm{g}^{-1}$ to $10^{6} \mathrm{CFU} \mathrm{mL} \mathrm{mL}^{-1} / \mathrm{g}^{-1}[15,48]$. Under low $\mathrm{pH}$ (as in squash) there is a possibility of increase in the lag phase and generation times of this organism [51], to let the organism multiply later. Thus, the inoculum was added at higher active cell concentration for toxin production. Bacillus cereus emetic toxins in squash were effective and toxic. Its presence in squashes (acidic product) among other products [15]-is one of the first reports and is a signal on quality defects that can arise in acidic fruit products, if preserved at room temperature $\left(\geq 30^{\circ} \mathrm{C}\right)$. In preparing a fruit squash, the juice is not heat-treated, and thus it is possible for entry of $B$. cereus from a raw material. B. cereus strain(s) can thus survive in storage. Orange Pineapple squash usually has a long shelf life (9-12 months). Contamination levels of this organism can reach between $10^{2}-10^{8} \mathrm{~g}^{-1}$, in various foods $[15,52]$. Due to heat and acid resistance of $B$. cereus and its toxin, the organism can survive and propagate in foods [52-54]. A multiplication of the organism to threshold levels can lead to emetic toxin production [47]. Thus, if not detected early in storage may cause serious hazard in foods. A prolonged storage of such products may contribute to sporulation until favorable conditions 
return for growth and toxin production by this organism. Hence storage periods should be carefully recommended and good manufacturing practices in all Food Processing units are needed. The contamination level should not exceed $100 \mathrm{CFU} \cdot \mathrm{g}^{-1} \mathrm{or} \mathrm{mL}^{-1}$ of food, to avoid the heat resistant toxin [52], which is adverse to hygiene [55, 56].

This study used CLM and B. cereus toxin in assay of vacuolar expansions as a first report, to the best of our knowledge, on the use of chicken liver tissue for vacuolar assay. There is a possibility of using polyclonal antibodies (Cellular WC-Ab, Toxin Tx-Ab of B. cereus), as a tool, to detect $B$. cereus or occurrence of emetic toxin, where molecular diagnostic facilities may not be accessible in Labs. Improvements in immunization schedule can help to obtain higher titer of the sera. To mention, the sera, obtained for these two Ags, have shown the possibility to detect other strains of emetic strains of B. cereus ( $15 \&$ not reported in this study). Their antigenicity can be used to further our knowledge and gain insights into B. cereus emetic toxin(s) and its antibodies. A large volume of high titer sera, required to detect large number of strains, is the only limitation.

The growth of $B$. cereus at temperatures $<48^{\circ} \mathrm{C}$ can cause food poisoning. To avoid this organism entering foods, a cook of $70{ }^{\circ} \mathrm{C}$ for $12 \mathrm{~s}$ can help to achieve a 6 Log reduction of $B$. cereus [57] as shown by a study on D-values $\left[\left(1 \mathrm{~min}\left(60^{\circ} \mathrm{C}\right)\right.\right.$ to $\left.33.2 \mathrm{~min}\left(50^{\circ} \mathrm{C}\right)\right]$ of $\mathrm{B}$. cereus vegetative cells]. In phosphate buffer the D-value was reported to be $10 \mathrm{~min}$ at $49-55^{\circ} \mathrm{C}$. A temperature of only $30^{\circ} \mathrm{C}$ can form spores of B. cereus [46]. The spores of B. cereus BC IV germinated in presence of alanine (1 mM-100 mM), at $30^{\circ} \mathrm{C}$ [15] (Fig. 9). Thus BC IV can propagate by spores at room temperature, in squash. The spores can allow the organism to escape pasteurization or sanitation procedures [58], due to its heat and acid resistance and can be problematic in convenience foods and mass catering. It is therefore important, to control B. cereus population [59] to avoid toxin production in foods. Hence the emetic toxin of $B$. cereus is certainly one of the most dangerous enterotoxins [60].

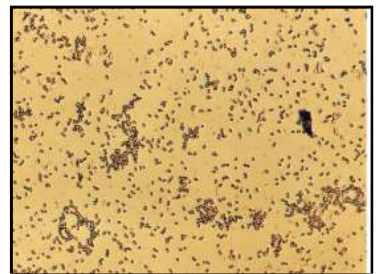

$a$

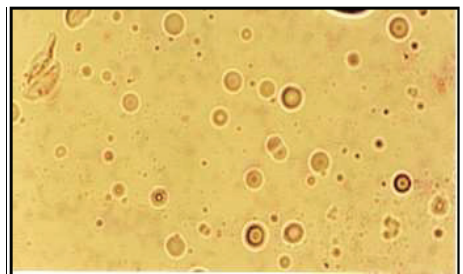

$b$

Fig. 9. Morphological features of Bacillus cereus BC IV:

$a$-gram stained cells of Bacillus cereus BC IV; $b$-Bacillus cereus BC IV spores

The PCR method has shown promise to detect a cereulide (emetic toxin) in Germany [61]. It is one of the most recent ways to detect the toxin. However series of at least 18 cereulide variants of emetic toxin have been reported to exist [62]. In India the detection or assay of this organism is not at a good scale. Its diversity in various Indian foods also needs to be studied. Among the serious damages, caused by emetic toxins, fulminant liver failure can be fatal, wherein the toxin can inhibit hepatic mitochondria fatty acid oxidation $[63,64]$. The loss of retinal structure and function $[65,66]$ is also a severe disorder due to emetic toxin of $B$. cereus. There is a need to create larger awareness on contaminated food(s) and food poisoning symptoms. Good manufacturing practices in food-processing units are again emphasized.

Bacillus cereus can be present on surfaces, sporulate and survive heat treatments (especially in dairy industry), where hygiene methods often are not able to control B. cereus. This is because the spores have high hydrophobicity and high adhesion ability for surfaces. An easy, fast and cheap detection method is also a limitation. To detect it by PCR method or by the use of antibodies requires skilled hands and may not always be available in the food industry. 
The awareness of consumer preference for food safety, easy possibilities of detection shown, may not remain a limitation in future for its inclusion in critical control points in HACCP programs, where $B$. cereus is a problem.

\section{Acknowledgements}

The authors are thankful to The Director, Central Institute of Agricultural Engineering (CIAE), Nabibagh, Berasia Road, Bhopal- Madhya Pradesh, 462038. India, to provide all facilities and also to extend academic support to the co-author, to complete a part of work reported herein, as part of her Masters Degree-Thesis document. We also thank The Head Division of Agro-Produce Processing Division, CIAE, Bhopal, for the necessary facilities and suitable conditions to carry out animal experimentations in Laboratory. The help, given by Pancham during the whole study period, is thankfully acknowledged.

\section{Conflict of interests.}

The authors have no conflict of interest.

\section{References}

[1] Newell, D. G., Koopmans, M., Verhoef, L., Duizer, E., Aidara-Kane, A., Sprong, H. et. al. (2010). Food-borne diseases - The challenges of 20years ago still persist while new ones continue to emerge. International Journal of Food Microbiology, 139, S3-S15. doi: https://doi.org/10.1016/j.ijfoodmicro.2010.01.021

[2] Van Netten, P., van de Moosdijk, A., van Hoensel, P., Mossel, D. A. A., Perales, I. (1990). Psychrotrophic strains of Bacillus cereus producing enterotoxin. Journal of Applied Bacteriology, 69 (1), 73-79. doi: https://doi.org/10.1111/j.1365-2672.1990. tb02913.x

[3] Gilbert, R. J., Parry, J. M. (1977). Serotypes of Bacillus cereus from outbreaks of food poisoning and from routine foods. Journal of Hygiene, 78 (1), 69-74. doi: https://doi.org/10.1017/s0022172400055947

[4] Yokoyama, K., Ito, M., Agata, N., Isobe, M., Shibayama, K., Horii, T., Ohta, M. (1999). Pathological effect of synthetic cereulide, an emetic toxin ofBacillus cereus, is reversible in mice. FEMS Immunology \& Medical Microbiology, 24 (1), 115-120. doi: https://doi.org/10.1111/j.1574-695x.1999.tb01272.x

[5] Kramer, J. M., Gilbert, R. J. (1989). Bacillus cereus and other Bacillus species. In: Food borne Bacterial Pathogens. New York, 21-70.

[6] Paananen, A., Mikkola, R., Sareneva, T., Matikainen, S., Hess, M., Andersson, M. et. al. (2002). Inhibition of human natural killer cell activity by cereulide, an emetic toxin from Bacillus cereus. Clinical \& Experimental Immunology, 129 (3), $420-428$. doi: https://doi.org/10.1046/j.1365-2249.2002.01898.x

[7] Thwaite, J. E., Atkins, H. S. (2012). Bacillus. Medical Microbiology, 237-244. doi: https://doi.org/10.1016/b978-0-70204089-4.00036-6

[8] Bryan, F. L., Bartleson, C. A., Christopherson, N. (1981). Hazard Analyses, in Reference to Bacillus cereus, of Boiled and Fried Rice in Cantonese-Style Restaurants. Journal of Food Protection, 44 (7), 500-512. doi: https://doi.org/10.4315/0362$028 \mathrm{x}-44.7 .500$

[9] Hughes, S., Bartholomew, B., Hardy, J. C., Kramer, J. M. (1988). Potential application of a HEp-2 cell assay in the investigation of Bacillus cereusemetic-syndrome food poisoning. FEMS Microbiology Letters, 52 (1-2), 7-11. doi: https://oi.org/ 10.1111/j.1574-6968.1988.tb02563.x

[10] Turnbull, P. C., Kramer, J. M., Jørgensen, K., Gilbert, R. J., Melling, J. (1979). Properties and production characteristics of vomiting, diarrheal, and necrotizing toxins of Bacillus cereus. The American Journal of Clinical Nutrition, 32 (1), $219-228$. doi: https://doi.org/10.1093/ajen/32.1.219

[11] Ahmed, A. A.-H., Moustafa, M. K., Marth, E. H. (1983). Incidence of Bacillus cereus in Milk and Some Milk Products. Journal of Food Protection, 46 (2), 126-128. doi: https://doi.org/10.4315/0362-028x-46.2.126

[12] Rodriquez, M. H., Barrett, E. L. (1986). Changes in Microbial Population and Growth of Bacillus cereus During Storage of Reconstituted Dry Milk. Journal of Food Protection, 49 (9), 680-686. doi: https://doi.org/10.4315/0362-028x-49.9.680

[13] Sooltan, J. R. A., Mead, G. C., Norris, A. P. (1987). Incidence and growth potential of Bacillus cereus in poultrymeat products. Food Microbiology, 4 (4), 347-351. doi: https://doi.org/10.1016/s0740-0020(87)80009-6

[14] Harmon, S. M., Kautter, D. A. (1991). Incidence and Growth Potential of Bacillus cereus in Ready-to-Serve Foods. Journal of Food Protection, 54 (5), 372-374. doi: https://doi.org/10.4315/0362-028x-54.5.372 
[15] Sunita, S. (2006). Final Report of the Project No. 502 "Establish/ modify assay for detection of Bacillus cereus and its toxin". Institute code No: P1-2004/4-IAE-Q 02 (ICAR code No. CIAE/APD/APD/2004-4. Available at: https://www.researchgate.net/ project/Establish-modify-assay-for-detection-of-Bacillus-cereus-and-its-toxin-ICAR-Code-No-PI-2004-4-IAE-Q-02-InstituteCode-No-CIAE-APD-2004-4-502-as-PI

[16] Melling, J., Capel, B. J. (1978). Characteristics of Bacillus cereusemetic toxin. FEMS Microbiology Letters, 4 (3), $133-135$. doi: https://doi.org/10.1111/j.1574-6968.1978.tb02849.x

[17] Granum, P. E., Lund, T. (2006). Bacillus cereus and its food poisoning toxins. FEMS Microbiology Letters, 157 (2), $223-228$. doi: https://doi.org/10.1111/j.1574-6968.1997.tb12776.x

[18] Van Netten, P., Kramer, J. M. (1992). Media for the detection and enumeration of Bacillus cereus in foods: a review. International Journal of Food Microbiology, 17 (2), 85-99. doi: https://doi.org/10.1016/0168-1605(92)90108-f

[19] Beattie, S. H., Williams, A. G. (1999). BACILLUS | Detection of Toxins. Encyclopedia of Food Microbiology, $141-149$. doi: https://doi.org/10.1006/rwfm.1999.0125

[20] Jääskeläinen, E. L., Teplova, V., Andersson, M. A., Andersson, L. C., Tammela, P., Andersson, M. C. et. al. (2003). In vitro assay for human toxicity of cereulide, the emetic mitochondrial toxin produced by food poisoning Bacillus cereus. Toxicology in Vitro, 17 (5-6), 737-744. doi: https://doi.org/10.1016/s0887-2333(03)00096-1

[21] Agata, N., Ohta, M., Yokoyama, K. (2002). Production of Bacillus cereus emetic toxin (cereulide) in various foods. International Journal of Food Microbiology, 73 (1), 23-27. doi: https://doi.org/10.1016/s0168-1605(01)00692-4

[22] Shinagawa, K., Otake, S., Matsusaka, N., Sugii, S. (1992). Production of the Vacuolation Factor of Bacillus cereus Isolated from Vomiting-Type Food Poisoning. The Journal of Veterinary Medical Science, 54 (3), 443-446. doi: https://doi.org/10.1292/ jvms.54.443

[23] Agata, N., Mori, M., Ohta, M., Suwan, S., Ohtani, I., Isobe, M. (1994). A novel dodecadepsipeptide, cereulide, isolated from Bacillus cereuscauses vacuole formation in HEp-2 cells. FEMS Microbiology Letters, 121 (1), 31-34. doi: https://doi.org/ 10.1111/j.1574-6968.1994.tb07071.x

[24] Suwan, S., Isobe, M., Ohtani, I., Agata, N., Mori, M., Ohta, M. (1995). Structure of cereulide, a cyclic dodecadepsipeptide toxin from Bacillus cereus and studies on NMR characteristics of its alkali metal complexes including a conformational structure of the K+ complex. Journal of the Chemical Society, Perkin Transactions 1, (7), 765. doi: https://doi.org/10.1039/p19950000765

[25] Carlin, F., Fricker, M., Pielaat, A., Heisterkamp, S., Shaheen, R., Salkinojasalonen, M. et. al. (2006). Emetic toxin-producing strains of Bacillus cereus show distinct characteristics within the Bacillus cereus group. International Journal of Food Microbiology, 109 (1-2), 132-138. doi: https://doi.org/10.1016/j.ijfoodmicro.2006.01.022

[26] Mikkola, R., Saris, N.-E. L., Grigoriev, P. A., Andersson, M. A., Salkinoja-Salonen, M. S. (1999). Ionophoretic properties and mitochondrial effects of cereulide. The emetic toxin of B. cereus. European Journal of Biochemistry, 263 (1), $112-117$. doi: https://doi.org/10.1046/j.1432-1327.1999.00476.x

[27] Ranganna, S. (1986). Handbook of analysis and quality control for fruit and vegetable products. New Delhi: Tata McGraw-Hill. Available at: https://www.worldcat.org/title/handbook-of-analysis-and-quality-control-for-fruit-and-vegetable-products/oclc/692163756

[28] Holbrook, R., Anderson, J. M. (1980). An improved selective and diagnostic medium for the isolation and enumeration of Bacillus cereus in foods. Canadian Journal of Microbiology, 26 (7), 753-759. doi: https://doi.org/10.1139/m80-131

[29] Collins, C. H., Lyne, P. M. (1976). Microbiological Methods. Butterworths Pub., 521.

[30] Lindbäck, T., Granum, P. E. (2013). Bacillus cereus. Guide to Foodborne Pathogens, 75-81. doi: https://doi.org/10.1002/ 9781118684856.ch4

[31] Andrews, W. H. (1984). A Perspective Review of the Development of AOAC Microbiological Methods. Journal of AOAC INTERNATIONAL, 67 (4), 661-673. doi: https://doi.org/10.1093/jaoac/67.4.661

[32] Grutsch, A. A., Nimmer, P. S., Pittsley, R. H., McKillip, J. L. (2018). Bacillus spp. as Pathogens in the Dairy Industry. Foodborne Diseases, 193-211. doi: https://doi.org/10.1016/b978-0-12-811444-5.00007-5

[33] Harrigan, W. F., McCance, M. F. (1976). Laboratory Methods in Food and Dairy Microbiology. Academic Press, 452.

[34] Varadaraj, M. C. (1993). Methods for detection and enumeration of food borne bacterial pathogens: A critical evaluation. Journal of Food Science and Technology, 30 (1), 1-13.

[35] JNU (1984). Biochemistry Practicals - A Handbook. School of Life Sciences, JNU, New Delhi, 48-49.

[36] Szabo, R. A., Speirs, J. I., Akhtar, M. (1991). Cell Culture Detection and Conditions for Production of a Bacillus cereus Heat-Stable Toxin. Journal of Food Protection, 54 (4), 272-276. doi: https://doi.org/10.4315/0362-028x-54.4.272

[37] Finlay, W. J. J., Logan, N. A., Sutherland, A. D. (1999). Semiautomated Metabolic Staining Assay for Bacillus cereus Emetic Toxin. Applied and Environmental Microbiology, 65 (4), 1811-1812. doi: https://doi.org/10.1128/aem.65.4.1811-1812.1999 
[38] Pressman, B. C. (1965). Induced active transport of ions in mitochondria. Proceedings of the National Academy of Sciences, 53 (5), 1076-1083. doi: https://doi.org/10.1073/pnas.53.5.1076

[39] Scheffler, I. E. (2001). A century of mitochondrial research: achievements and perspectives. Mitochondrion, 1 (1), 3-31. doi: https://doi.org/10.1016/s1567-7249(00)00002-7

[40] Spector, I., Palfrey, C., Littauer, U. Z. (1975). Enhancement of the electrical excitability of neuroblastoma cells by valinomycin. Nature, 254 (5496), 121-124. doi: https://doi.org/10.1038/254121a0

[41] Einar, G. P. (1997). Bacillus cereus. In: Fundamentals in Food Microbiology. American Society for Microbiology, Washington DC., 327-336.

[42] El-Arabi, T. F., Griffiths, M. W. (2013). Bacillus cereus. Foodborne Infections and Intoxications, 401-407. doi: https://doi.org/ 10.1016/b978-0-12-416041-5.00029-9

[43] Isobe, M., Ishikawa, T., Suwan, S., Agata, N., Ohta, M. (1995). Synthesis and activity of cereulide, a cyclic dodecadepsipeptide ionophore as emetic toxin from Bacillus cereus. Bioorganic \& Medicinal Chemistry Letters, 5 (23), 2855-2858. doi: https:// doi.org/10.1016/0960-894x(95)00503-1

[44] Product Review- Kissan Orange Squash. Available at: https:/foodnetindia.in/product-review-kissan-orange-squash/

[45] Guinebretière, M.-H., Thompson, F. L., Sorokin, A., Normand, P., Dawyndt, P., Ehling-Schulz, M. et. al. (2008). Ecological diversification in the Bacillus cereus Group. Environmental Microbiology, 10 (4), 851-865. doi: https://doi.org/10.1111/ j.1462-2920.2007.01495.x

[46] Mitscherlich, E., Marth, E. H. (1984). Microbial Survival in the Environment. Bacteria and Rickettsiae Important in Human and Animal Health. Springer, 803. doi: https://doi.org/10.1007/978-3-642-69974-0

[47] Häggblom, M. M., Apetroaie, C., Andersson, M. A., Salkinoja-Salonen, M. S. (2002). Quantitative Analysis of Cereulide, the Emetic Toxin of Bacillus cereus, Produced under Various Conditions. Applied and Environmental Microbiology, 68 (5), 2479-2483. doi: https://doi.org/10.1128/aem.68.5.2479-2483.2002

[48] Te Giffel, M. C., Beumer, R. R., Leijendekkers, S., Rombouts, F. M. (1996). Incidence of Bacillus cereus and Bacillus subtilis in foods in the Netherlands. Food Microbiology, 13 (1), 53-58. doi: https://doi.org/10.1006/fmic.1996.0007

[49] Goepfert, J. M., Spira, W. M., Kim, H. U. (1972). Bacillus cereus: food poisoning organism. A review. Journal of Milk and Food Technology, 35 (4), 213-227. doi: https://doi.org/10.4315/0022-2747-35.4.213

[50] Johnson, K. M. (1984). An Update. Journal of Food Protection, 47 (2), 145-153. doi: https://doi.org/10.4315/0362-028x-47.2.145

[51] Benedict, R. C., Partridge, T., Wells, D., Buchanan, R. L. (1993). Bacillus cereus: Aerobic Growth Kinetics. Journal of Food Protection, 56 (3), 211-214. doi: https://doi.org/10.4315/0362-028x-56.3.211

[52] Kimanya, M. E., Mamiro, P. R. S., Van Camp, J., Devlieghere, F., Opsomer, A., Kolsteren, P., Debevere, J. (2003). Growth of Staphylococcus aureus and Bacillus cereus during germination and drying of finger millet and kidney beans. International Journal of Food Science and Technology, 38 (2), 119-125. doi: https://doi.org/10.1046/j.1365-2621.2003.00652.x

[53] Kamat, A. S., Nerkar, D. P., Nair, P. M. (1989). Bacillus cereus in some indian foods, incidence and antibiotic, heat and radiation resistance. Journal of Food Safety, 10 (1), 31-41. doi: https://doi.org/10.1111/j.1745-4565.1989.tb00005.x

[54] Kanda, K., Yasuda, Y., Tochikubo, K. (1991). Germination response of Bacillus subtilis PCI219 Spores to Caramelized Sugar and 1-Asparagine. Journal of Food Science, 56 (5), 1399-1403. doi: https://doi.org/10.1111/j.1365-2621.1991.tb04783.x

[55] Lattuada, C. P., McClain, D. (1998). Examination of meat and poultry products for Bacillus cereus. USDA/FSIS. Microbiology Laboratory Guidebook. Available at: http://docshare04.docshare.tips/files/10169/101693424.pdf

[56] Eley, A. R. (1992). Toxic bacterial food poisoning. Microbial Food Poisoning, 37-55. doi: https://doi.org/10.1007/978-1-48993121-4_3

[57] Byrne, B., Dunne, G., Bolton, D. J. (2006). Thermal inactivation of Bacillus cereus and Clostridium perfringens vegetative cells and spores in pork luncheon roll. Food Microbiology, 23 (8), 803-808. doi: https://doi.org/10.1016/j.fm.2006.02.002

[58] Machaiah, M. I., Krishnan, M. H. (2014). Immunodetection of Bacillus cereus haemolytic enterotoxin (HBL) in food samples. Analytical Methods, 6 (6), 1841. doi: https://doi.org/10.1039/c3ay41737a

[59] Notermans, S., Tatini, S. (1993). Characterization of Bacillus cereus in relation to toxin production. Nederlands melk en Zuiveltijdschrift, 47 (2), 71-77. Available at: http://pascal-francis.inist.fr/vibad/index.php?action=getRecordDetail\& $\mathrm{idt}=3916662$

[60] Andersson, M. A., Mikkola, R., Helin, J., Andersson, M. C., Salkinoja-Salonen, M. (1998). A Novel Sensitive Bioassay for Detection ofBacillus cereus Emetic Toxin and Related Depsipeptide Ionophores. Applied and Environmental Microbiology, 64 (4), 1338-1343. doi: https://doi.org/10.1128/aem.64.4.1338-1343.1998

[61] Ehling-Schulz, M., Fricker, M., Scherer, S. (2004). Identification of emetic toxin producing Bacillus cereus strains by a novel molecular assay. FEMS Microbiology Letters, 232 (2), 189-195. doi: https://doi.org/10.1016/s0378-1097(04)00066-7 
[62] Marxen, S., Stark, T. D., Frenzel, E., Rütschle, A., Lücking, G., Pürstinger, G. et. al. (2015). Chemo-diversity of cereulide, the emetic toxin of Bacillus cereus. Analytical and Bioanalytical Chemistry, 407 (9), 2439-2453. doi: https://oi.org/10.1007/ s00216-015-8511-y

[63] Mahler, H., Pasi, A., Kramer, J. M., Schulte, P., Scoging, A. C., Bär, W., Krähenbühl, S. (1997). Fulminant Liver Failure in Association with the Emetic Toxin of Bacillus cereus. New England Journal of Medicine, 336 (16), 1142-1148. doi: https:// doi.org/10.1056/nejm199704173361604

[64] Sakurai, N., Koike, K. A., Irie, Y., Hayashi, H. (1994). The Rice Culture Filtrate of Bacillus cereus Isolated from Emetic-Type Food Poisoning Causes Mitochondrial Swelling in a HEp-2 Cell. Microbiology and Immunology, 38 (5), 337-343. doi: https:// doi.org/10.1111/j.1348-0421.1994.tb01788.x

[65] Kopel, A. C., Carvounis, P. E., Holz, E. R. (2008). Bacillus Cereus Endophthalmitis Following Intravitreous Bevacizumab Injection. Ophthalmic Surgery, Lasers, and Imaging, 39 (2), 153-154. doi: https://doi.org/10.3928/15428877-20080301-10

[66] Moyer, A. L., Ramadan, R. T., Novosad, B. D., Astley, R., Callegan, M. C. (2009). Bacillus cereus-Induced Permeability of the Blood-Ocular Barrier during Experimental Endophthalmitis. Investigative Opthalmology \& Visual Science, 50 (8), 3783. doi: https://doi.org/10.1167/iovs.08-3051

Received date 26.02.2021

Accepted date 22.03.2021

Published date 31.03.2021
(C) The Author(s) 2021 This is an open access article under the CC BY license (http://creativecommons.org/licenses/by/4.0).

How to cite: Singh, S., Lad, P. (2021). Assay of Bacillus cereus Emetic toxin produced in orange squash. EUREKA: Life Sciences, 2 , 41-55. doi: https://doi.org/10.21303/2504-5695.2021.001753 